\title{
IDENTITY CHANGES IN THE SLOVENIAN AND FRIULIAN LINGUISTIC COMMUNITIES IN THE PROVINCE OF UDINE, FRIULI-VENEZIA GIULIA, ITALY
}

Danila Zuljan Kumar ${ }^{1}$

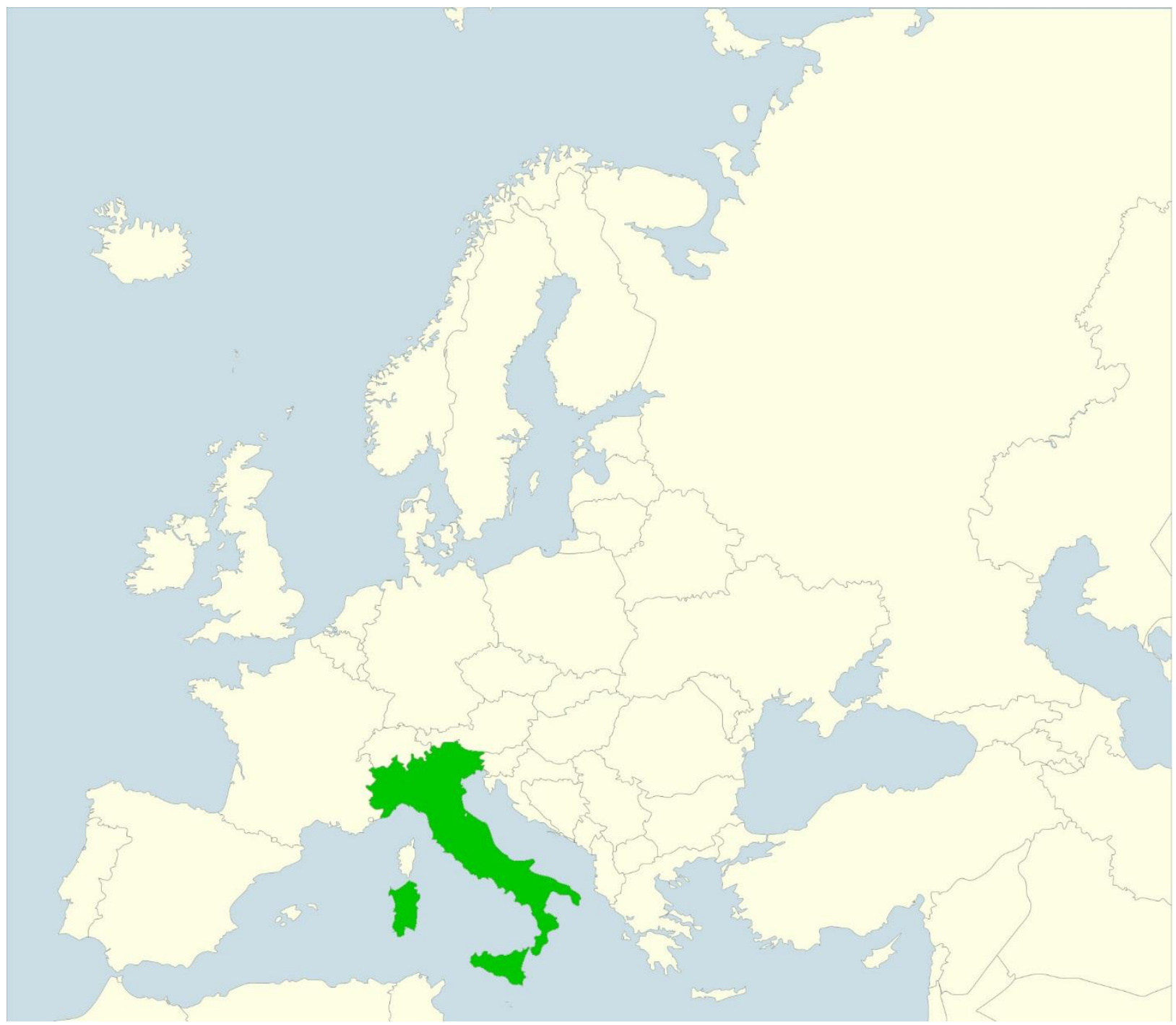

${ }^{1}$ Ass. Prof. Danila Zukjan Kumar, PhD., Fran Ramovš Institute of the Slovenian language, Slovenian Academy of Sciences and Arts, Novi trg 4, 1001 Ljubljana, Slovenia; e-mail: danila.zuljan@zrc-sazu.si 
Abstract: The paper discusses the intertwined relationship between identity construction, language practices and language ideologies of Slovenes and Friulians in the Province of Udine, Friuli Venezia Giulia, Italy. We are dealing with two indigenous linguistic minorities whose native language was historically restricted to the private sphere of life. However, due to altered social conditions of decentralization and globalization, the ever-increasing use of these languages outside private sphere has been noticed. The phenomenon will be illuminated by the statements of the members of both linguistic minorities. The final part of the paper will present the reawakening of a dying culture and language of the village of Topolove through an art festival, called Postaja Topolove/Stazione Topolò, whose basic concept is to avoid folklorism and create the most advanced artwork search.

Key words: minority language, identity, Province of Udine, Slovenes, Friulians

Izvleček: Članek predstavlja prepleten odnos med vzpostavljanjem identitete, identitetnimi praksami in jezikovnimi ideologijami, kot se kaže pri Slovencih in Furlanih v Videmski pokrajini Furlanije-Julijske krajine v Italiji. Gre za dve avtohtoni jezikovni manjšini, pri katerih je bil materni jezik $v$ preteklosti omejen na zasebno sfero življenja, $v$ spremenjenih družbenih razmerah decentralizacije in globalizacije pa je opaziti njuno vse pogostejšo rabo tudi izven zasebnega okolja, kar bomo v prispevku dokazovali z izjavami govorcev obeh jezikovnih manjšin. $\vee$ zadnjem delu prispevka bo osvetljeno oživljanje izumirajoče kulture in jezika vasi Topolove $v$ Beneški Sloveniji skozi umetnost na primeru festivala Postaja Topolove/Stazione Topolò, katerega osnovni koncept je izogibanje folklorizmu in ustvarjanje najnaprednejšega umetniškega iskanja.

Ključne besede: manjšinski jezik, identiteta, Videmska pokrajina, Slovenci, Furlani

\section{Introduction}

The salient feature of linguistic and cultural landscape of Friuli Venezia Giulia (henceforth FVG), which, like the regions of Valle d'Aosta, Trentino Alto Adige, Sicily and Sardinia, enjoys a special autonomy within the Italian state, is its diversity. The region which borders Slovenia and Austria is settled by three linguistic minority groups: Slovenian, Friulian and German-speaking minorities, whose common denominator is their autochthony, i.e. historical presence in the area where they live today. In the past, regional languages and their local variants (such as are Friulian, Slovenian and German variants in FVG) used to symbolize backwardness because they were primarily spoken in rural areas and were not used outside private sphere. However, the perception of these languages either among the speakers themselves or among the majority population has changed, as it will be demonstrated in the following chapters.

Friulian, variously referred to as furlan, lenghe furlane or marilenghe (it. friulano) is a Romance language which together with Romansh and Ladin forms the so-called Rhaeto-Romance subfamily of Romance languages. ${ }^{2}$ It is attested to be in written texts since 1150 and has been in literary use since the $14^{\text {th }}$ century. Throughout history Friulian has been influenced by various languages with which it came into contact: the pre-Romance languages such as Gaelic and Venetic, by Germanic languages such as Gothic Langobardic and German, and by Slavic languages (Vicario, 2015, p. 27; Frau, 2014, pp. 73-84). There are two elements associated with the political history of Friuli that were decisive for the development of Friulian language: the first is the domination of the Longobards who came to Friuli to settle there permanently in 568 and

\footnotetext{
2 The so-called Rhaeto-Romance theory (la teoria della questione ladina) formed by the Italian linguist G. I. Ascoli and then corrected and specified by G. Francescato is not being shared by some scholars, e.g. C. Battisti, C. Tagliavini in G. B. Pellegrini. More on that question see in Heinemann (2015).
} 
made Forum Juli (Cividale), whence the name Friuli, the capital of their first dukedom (Salimbeni, 2014, p. 6; Frau 2015, p. 78), and the second one is the fact that in the period of the Patriarchate of Aquileia (between the $11^{\text {th }}$ and $15^{\text {th }}$ centuries), the language continued to be spoken among the common people, while the ruling elite spoke German. The transition under the rule of the Venetian Republic in 1420 brought the supremacy of the Venetian dialect over the Friulian language and the community's incorporation into the Italian cultural context (Vidau, 2013, p. 33).

According to the traditional Italian classification, Friulian is ranked as the language of a linguistic minority, which means that its speakers are bearers of Italian culture and identity, who use particular linguistic varieties (Iannàccaro; Dell'Aquila 2015, p. 454). Figures for Friulian speakers vary between 430,000 and 625,000 depending on whether occasional speakers of Friulian and Friulanophones residing outside Friuli are included in the estimate or not (Mucignat, 2014, p. X, cf. Petris, 2014, p. 8). Some estimates taking into account people's cultural sense of belonging to the Friulian community, go even to the number 850,000 (Vidau, 2013, p. 34). Nevertheless, it is difficult to quantify in detail the actual number of Friulians (and the same holds true for Slovenes) in FVG, because of the lack of updated linguistic census data and also because of the fact that those who speak Friulian are multilingual (Susič et. al, 2010, p. 139).

In the last few years, several legal and administrative policies have been introduced to preserve the Friulian linguistic and cultural heritage ${ }^{3}$ but despite these efforts, Friulian is ranked by UNESCO as a "definitely endangered" language, indicating that children no longer learn it as their mother tongue at home (Moseley, 2010). At school, Friulian is only taught as a school subject and through different projects, which depend on funding and teacher's competences and determination (Petris, 2014, p. 22), although in accordance with the article 4 of Law 482/1999, Friulian may also be taught as a medium of instruction (cf. Petris, 2014, p. 22).

The history of Slovenes in Italy dates back to the $6^{\text {th }}$ to the $8^{\text {th }}$ centuries, when the Slavic tribes settled on the eastern borders of the region, on the hills behind Cividale and in the Karst of the Isonzo and Trieste areas (Štih, 2013, p. 82-83; Ramovš, 1995, p. 23; Logar, 1996, p. 3-4; Salimbeni, 2014, p. 6). Slovenian, precisely its Ter/Torre Valey dialect was first recorded in 1479, in the Cividale manuscript. ${ }^{4}$

An important milestone for Slovenes in the Province of Udine was the year 1866 when they were annexed to Italy, while the Slovenes in the Provinces of Trieste and Gorizia remained within the jurisdiction of the Austrian state. After the Second World War, Italy annexed the towns of Gorizia and Trieste. Slovenes, living in these two provinces, enjoyed the status of linguistic minority with all its associated rights (basic education, language of administration) as far back as the post-war period, while the Slovenes living in the Province of Udine gained the status of a historical linguistic minority only in the year 1999 by the Law for the Protection of Historical Linguistic Minorities in FVG (Regional Law 482/1999). ${ }^{5}$ However, primary education in Slovenian as one of the two languages of instruction (beside Italian) began in 1984, with the establishment of bilingual school centre in San Pietro al Natisone/Špeter, which first operated as a private school and was subsequently incorporated into the state school system.

\footnotetext{
3 The protection of the Friulian linguistic minority is based on three laws: Regional Law n. 15, which was adopted in 1996 and brought the official recognition of the Friulian linguistic community, State Law n. 482/1999, which made it possible to complete and enlarge the areas of protection already defined by regional legislation, and Regional Law 29/2007, entitled "Norme .per la tutela e la valorizzazione e promozione della lingua friulana" (Law for the protection, valorisation and promotion of the Friulian language), which, among other things, regulates linguistic policy, curricular teaching of the Friulian language and the training of teachers. For further reading see Cisilino (2014, pp. 15-27); Cisilino (2015, pp. 475-491).

${ }^{4}$ More on the relationship between Slovenian, Friulian and Italian speaking inhabitants in the border area in the Early Modern Period see in Makuc (2015).

5 The protection of the Slovenian linguistic minority is based on three laws: State Law n. 482/1999, Law 38/2001, which regulates the situation of the Slovenes in all three provinces, and Regional Law 26/2007, which forms part of the regional policy strategies aimed at protecting and supporting the Slovenian linguistic minority in FVG. However, it is important to note here that despite the adopted legislation there are still unsolved questions concerning the public use of minority and regional languages in FVG, e.g. the project based funding system which does not enable public administrations to cover the costs of permanently employed stuff (Vidau, 2012).
} 


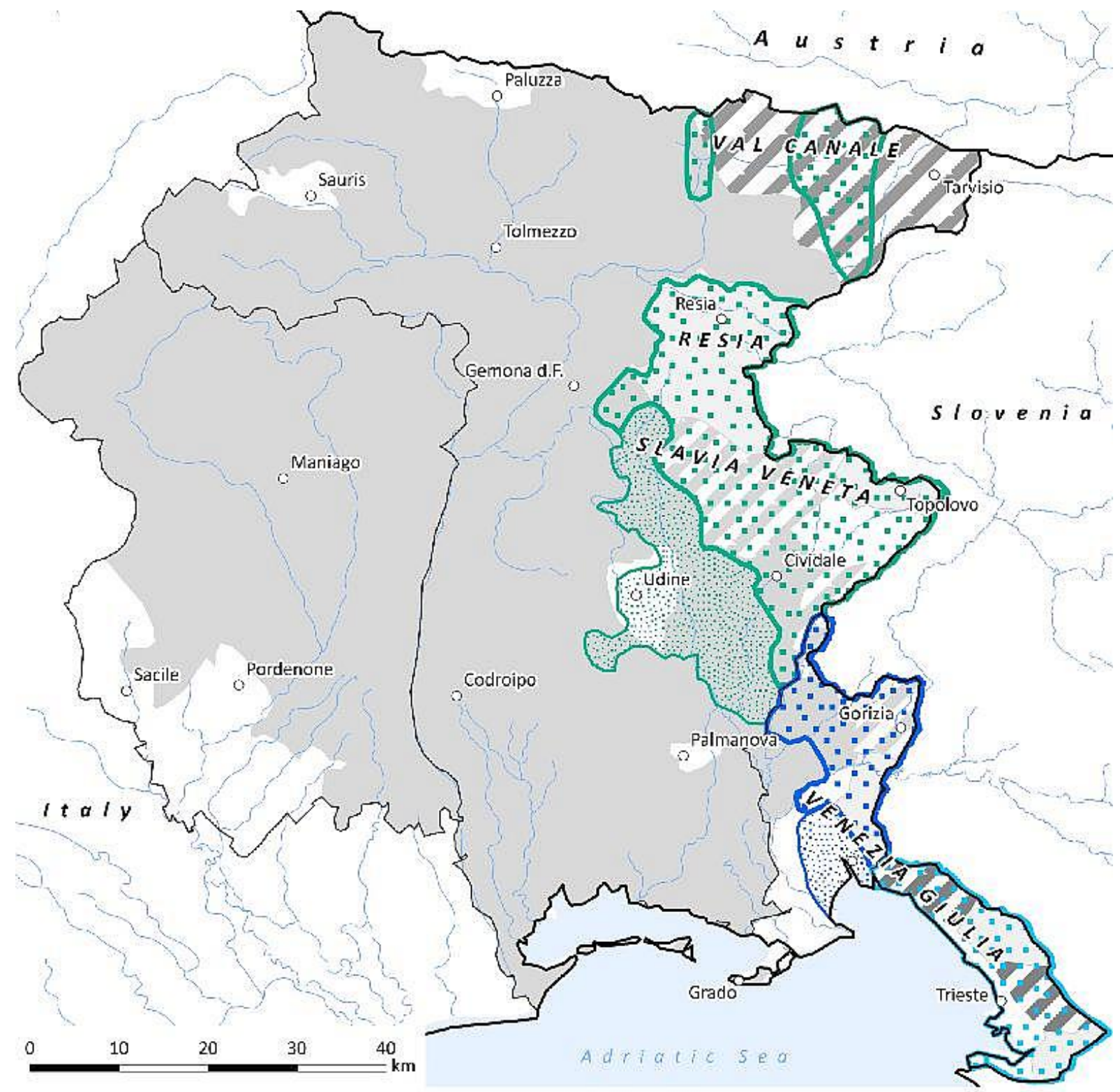

\section{Legend}

Traditional Slovene areas in the Province of

a". Trieste

[.] Gorizia

Udine

Areas with in-migrated Slovenes in

Gorizia

Udine

Spread of Friulian language Spread of Slovene language

Mixed areas with German, Slovene and Friulian languages

Mixed areas with Slovene and Veneto dialect

Mixed areas with Slovene and Friulian languages

Source: Eurostat

(C) Anton Melik Geographical Institute ZRC SAZU

Fig 1. Area under study.

According to the traditional Italian classification, Slovenian in Italy is ranked as the language of a national minority (lannàccaro \& Dell'Aquila, 2015, p. 454) with the total number of 46,000 speakers $(25,000$ living in the Province of Trieste, 11,000 in the Province of Gorizia and 10,000 in the Province of Udine (Steinicke et. al., 2016, p. 54).

The focus of this paper are Slovenes and Friulians of the Province of Udine, the former living in predominantly hilly area known as Slavia Veneta (Beneška Slovenija), in Val Canale and Val Resia, while the Friulians mainly live in the levelled part of the province. In the article, I will concentrate only on the Slovenes living in Slavia Veneta and not on all three areas mentioned. It is important to note that the researched area has been faced with heavy population losses caused 
by high emigration process from the mountainous villages or due to the high birth deficits (Steinicke et al., 2016, pp. 58-59). ${ }^{6}$

In the past, the use of Slovenian and Friulian in this territory was limited to the private sphere and particularly to communication in rural areas, while only Italian was used publicly. As a spoken language in towns, the urban varieties of Venetian dialect of Italian, strongly influenced by Friulian substrate, were mainly used (il veneto udinese, il veneto pordenonese, il veneto triestino e muggesano, il veneto bisiàcco) and considered a more prestigious code of communication compared to Friulian (Fusco, 2015, p. 300). But, as argued by Fusco, in recent years, the value the speakers in Friuli attribute to veneto udinese is more or less negative considering it a hybrid variety that should be removed from the community's repertoire, while the use of Friulian should be promoted (Fusco, 2015, p. 301). The tendency towards the revitalization of Friulian and the promotion of its use in public life by its speakers, described in Fusco, does not represent an isolated case. Changes of attitude in the use of Friulian and Slovenian can be noticed from the speakers' statements, the newspapers' articles, the scientific research (cf. Fusco, 2015; Coluzzi, 2015; Melchior, 2015; Steinicke et al., 2016; Vidau, 2015; Vidau, 2012; Sillani et al., 2011; Burelli, 2011; Picco, 2008, Bogatec et al., 2004) as well as in the linguistic landscape (on public and commercial signs), although the latter still on a small scale (Mezgec, 2016).

The phenomenon can be related to, firstly, the presence of Slovenian in bilingual school centre in San Pietro al Natisone/Špeter (and to a smaller degree to the introduction of Friulian into primary education) and, secondly, to the changes of attitude of authorities towards the two linguistic communities. The latter can be put into a frame of broader social changes in the relation to minority, regional and local languages in European Union, i.e. the promotion of linguistic diversity led by the European policies.

\section{Changes of attitude towards minority, regional and local languages in Europe}

In Europe, the first signs of changes of attitude towards minority and regional languages began to appear in the late $70 \mathrm{~s}$ of the $20^{\text {th }}$ century, as a result of changes of attitude of governments towards these languages. Liliane Vassberg, who was exploring the relationship of the Alzatians towards their Germanic language in France, reports that their attitude towards their own regional language, in relation to the dominant French, gradually changed due to changed attitude of the French Government towards such languages. With the introduction of the minority and regional languages to schools, the Government significantly contributed to the positive attitude of people towards their mother tongue (Vassberg, 1993, p. 2).

Dow states that, in the 50 s and 60 s of the $20^{\text {th }}$ century, young Germans associated the use of regional and local languages with the Nazi period, with their 'blood and soil' ethos. Now, however, young educated people tend to use these languages to show their solidarity with the working class (Dow, 2010, p. 233). There is a growing interest in researching German regional and local languages outside German political borders. In 2008, the University of Marburg commenced an extensive survey of German dialects as representatives of German linguistic identity. A vast grant has been awarded to the German Language Atlas - REDE (Regionalsprache.de), based on the fact that despite more than 180 year tradition of research of the German dialects, there is no comprehensive study of modern regional spoken languages available (Dow, 2010, p. 234).

The use of minority and regional languages is not only encouraged, but there is also a reinforcing tendency toward revival of disappearing languages such as Celtic, Irish, Breton Gaelic, Welsh and many trivial, local languages. It is interesting that some of the reawakened cultures do not reflect as much through policy and formal institutions as in the $19^{\text {th }}$ century, during the great awakening, when political demands were, as a rule, associated with formal request towards recognition of a language and its introduction to schools, administration and public life, but through (popular) culture, i.e. music festivals, drama, poetry, etc., as in the case of the Welsh (Williams, 2010, p. 244). Movies and other forms of visual art are being recorded in dying regional and local

\footnotetext{
6 The municipality of Drenchia/Dreka, for example, has lost more than $90 \%$ of its population, the entire Slavia Veneta over $77 \%$ since WWII (Steinicke et al. 2016, p. 58).
} 
languages, such as in the Sámi language (Huss, Lindgren, 2010, pp. 263-264; Markelin et al., 2013). Movies, recorded in such languages successfully participate in film festivals, breaking the stereotypical thinking that regional and local languages cannot compete with 'major' languages because of their geographical limitations. In Italy, we can witness the revival of Cymbrian, a Tyrolean-Bavarian dialect spoken north of Verona and Vicenza, which dates back to the $9^{\text {th }}$ century AD (Dow, 2010, p. 234). There are now folk festivals, daily newspapers etc., where this language can be heard (Dow, 2010, p. 234).

Promotion of the use of minority and regional, and revitalization of almost extinct languages, was not initiated only by government efforts of decentralization, supported by EU policies, but is also a 'merit' of globalization. On the one hand, globalization destabilized ethnic cultures and undermined national languages (especially their use in international communication). On the other hand, it also initiated the process of in-depth awareness of belonging to a small, local and regional area and sharpened the view of specificities of both, consolidated and individual national, regional and local identities and linguistic characteristics, associated with them (Rizman, 2003; Fakin Bajec, 2016; Fakin Bajec, 2011). Therefore, we can presently talk about two parallel processes of changing identity: the proliferation of identity and its narrowing (Huntington, 2004, pp. 13-14). Nowadays, we can easily communicate with distant and different cultures and civilizations, which provide new opportunities of identifications (proliferation of identity). Nevertheless, an individual may feel lonely and helpless with the choice of countless opportunities, which stimulates search for a more intimate, more personal identification associated with a local environment, its habits in everyday social life and ritual practices. On the one hand, there is a threat of cultural fusion of globalization, but on the other hand, the above examples of awakening of regional and local identities, show the opposite, as illustrated by J. A. Fishman, who states that:

"Some of the very processes of globalization and post-modernism that were supposed to be most deleterious to purportedly 'parochial' identities have actually contributed most to their re-emergence as 'part-identities'. The increasing ubiquity of the civil state, of civil nationalism and therefore, of a shared supra-ethnic civil nationalism as part of the identity constellation of all citizens, has resulted in more rather than less recognition of multiculturalism at the institutional level and a more widespread implementation of local ethnicity as a counterbalance to civil nationalism at the level of organized part-identity" (Fishman, 2001, p. 460).

Minority, regional and local languages present one of the keys of preservation of differences between regions and local environments. Their use, therefore, reflects regional and local awareness of the speaker, his loyalty to the local environment and respect for history of the area in which the language is spoken and to the people who speak this particular language (Vassberg, 1993, p. 158). In other words, the speaker's perception of himself as belonging to a particular linguistic community is also reflected in his speech behaviour.

Regional and especially local languages primarily relate to the rural environment, which used to symbolize backwardness and lack of education, but in recent years, the use of these languages is slowly discarding an associative relationship to the lack of civilization, because of the changes in understanding of the rural environment. Today, when people gradually distance themselves from the urban environment to the peace of the countryside, this move is valued differently.

The purpose of my paper is to demonstrate how, under the influence of broader social changes, in recent years, the attitude of the Slovenes in Slavia Veneta and Friulians in the use of their language in public life (i.e. in relation to Italian) is gradually changing. Nevertheless, to understand this process, it is necessary to illuminate the relationship between language, language practices, identity construction and language ideologies.

\section{Identity and language. Theoretical background}

The intertwined relationship between language practices, identity construction and language ideologies has attracted much of researchers' interest. For example, Joseph argues that 
"language and identity are ultimately inseparable" (Joseph, 2004, p. 13), in a way that "identity is itself at the very heart of what language is about" (Joseph 2004, p. 224) and, on the other hand, language is in the sense of what a person says or writes, "central to individual identity" (Joseph, 2004 , p. 225). The language we speak thus represents an important part of our awareness of who we are. It is one of the key identity markers of an individual or a group as individual and collective identities are constructed through a language or, more specifically, through the linguistic system of a language (Pavlenko \& Blackledge, 2004, p. 14).

Each language community organizes and articulates its own world differently, in its own unique way. Each language ${ }^{7}$ has its own unique structural system (phonology, morphology, syntax, lexicon) connected with the cultural system in which it is used, in other words, the meanings and forms of linguistic signs are established by the speakers of a language community (Preston, 1997, p. 6). Or, as Dorian states, "Each of the languages in the world carries human experience in its own way and it can be stated that each of them holds a special talent in ways how they form structures that carry meanings" (Dorian, 2010, p. 96).

Furthermore, Joseph points out that a person's "self-representation of identity is the organizing and shaping centre of his/her representations of the world" (Joseph, 2004, p. 20). He underlines that the people's use of language cannot be reduced to "how meaning is formed and represented in sound or communicated from one person to another", but has to be put into the frame of who communicates, i.e. people themselves, as "their identity inheres in their voice, spoken, written or signed" (Joseph, 2004, p. 21). The importance is, therefore, not in an object, a thing or a man, but in the meaning that people through language attribute to an object, a thing or a man. In this regard, languages are essentially systems of representation (Hall, 1997, p. 4).

People who belong to the same culture, have to share the common system of interpretation of linguistic signs, as it is the only way they can effectively exchange meanings among themselves (Hall, 1997, p. 19). This mutual system is important for the successful exchange of information, but it also has a strong symbolic value (Bourdieu 2009), as it represents a bond with the community's history, its ancestors and its cultural values.

Through language cultural values are transmitted from parents to children; through language children develop a sense of community and attachment to their families. If parents have positive approach to their mother tongue, the same approach will be adopted by the child and vice versa (Hall, 1997, p. 142). It is also true that if a language, spoken by the child, enjoys a status of a submissive language within a dominant social group, i.e. it is regarded as an inferior language with a low indexical value that can index only local matters, the child understands that he is a member of a group whose language and culture are not respected in the eyes of the dominant and more powerful group (Padilla \& Borsato, 2010, p. 12). In this sense, language is the place where actual forms of social organizations and their likely social and political consequences are defined and contested (Weedon, 1997, p. 21). Language ideologies and indexical values are closely related in that the latter are derived from the speakers' beliefs about the values of a particular language and their perceptions of a particular social group. They play an important role in structuring "dominant-subordinate, majority-minority relations" (Creese \& Blackledge, 2011 , p. 197), and thus have significant effect on discursive practices of speakers of that language. In other words, discursive practices are closely related to the political and ideological meanings of a particular language as well as to power relations between languages spoken in the same social context.

However, it is important to note that beliefs about languages are socially and culturally constructed and that language ideologies are not fixed or static (Kroskrity, 2010). The changed social conditions, in which the use of a specific language becomes acceptable, or even considered as a value, influence the attitude towards the language on the part of its speakers and the speakers of a majority language. Namely, researchers constantly observe that the use of a language and expression of identity change depending on context (cf. Zuljan Kumar, 2016; Zuljan Kumar, 2011; Grof, Pilote \& Vieux-Fort, 2016; Marriou, 2012; Pietkäinen, 2012; Schmidt, 2008). Or, in other

\footnotetext{
${ }^{7}$ Language spoken here is understood as speech code in general, which, in addition to formal, also includes regional and local varieties.
} 
words, changing social conditions always trigger changes in the speakers' shared social beliefs (i.e. language ideologies) about a particular language and consequently, in their discursive practices.

In the sections to follow, I shall demonstrate changes in the relationship to the Slovenian and Friulian in the Province of Udine, Friuli Venezia Giulia, Italy.

\section{Language practices, identity construction and language ideologies of the Friulians and Slovenes in the province of Udine. The study and methodological frame}

The paper presents the results of broader research based on the interviews with Slovenian and Frulian speakers. In total, 22 semi-structured qualitative sociolinguistic interviews were carried out in the period between 2012 and 2015 with 11 Slovenian and 11 Friulian speakers, aged from 25 to $76 .{ }^{8}$ I conducted all the interviews with the members of the Slovenian minority myself; I also carried out three interviews with Friulian speakers, while the rest of the interviews were conducted by a student, Vlasta Križman, as part of research for her graduation thesis. ${ }^{9}$ Furthermore, the paper presents the findings from the previous studies on the topic and statements of speakers of both minorities published in daily newspapers.

In the past, the attitude of the majority population towards Slovenes and Friulians in the Province of Udine was based on a highly contradictory relationship of a dominant linguistic group speaking 'cultivated' language against the minority linguistic group speaking 'underdeveloped' language or dialect. This was reflected in the attitude of Slovenes and Friulians towards their own language, which can be illustrated by a statement of an Italian female speaking about the relationship of her peer Slovenes to their own language:

"I was born in Cividale, where I grew up. [...] Regardless of the fact that I am Italian, half of my classmates were Benečani. ${ }^{10} \mathrm{I}$ remember that they were embarrassed to talk about their customs and culture from which they originated. I felt it" (S. B., 2012). ${ }^{11}$

Similar hiding of the Slovenian identity was experienced by a male Friulian, who spent his childhood among the Slovenes in the town of Tarvisio:

"When I lived in the Canale Valley, [...] I met with Slovenian character, which was then semi-hidden. In fact, I did not know that the neighbors, whose last name was, for example, Vencelj, were Slovenes. At that time, namely, German example was promoted in the Canale Valley. The prevailing view was that the population, who spoke a different language, was of a German or mixed origin. Slovenes themselves, which, in the Canale Valley, mostly also speak German, did not expose their nationality and they preferred to hide under German nationality and culture" (R. D., 2003).

Friulians also used their mother tongue only in the private sphere in the past, in a family environment, in rural areas, and did not expose their identity publicly. "Loyalty to our stuff has always been a family thing, a decision of an individual," explains two of the interviewees (P. G., 2013; A. M., 2013), and the latter underlines that "many have lost the awareness of being Friulians during the time of fascism, when they 'cut their wings' of being Friulians" (A. M., 2013). The statement refers to the time when the fascists seized power (in 1923), and when the Slovenes

\footnotetext{
8 Interviewees, whose statements are cited, are named in the article by their initials.

${ }^{9}$ Each interview lasted for about an hour and the basic questions were: What defines you as a Slovene/Friulian? Is language in your opinion the most important signifier of your Slovenian/Friulian identity? In which (social) group in your opinion is Slovenian/Friulian identity most strongly expressed and Slovenian/Friulian language most in use? Which language/languages do you use in your family? What in your opinion is the difference between the expression of Slovenian/Friulian identity in the past and today? How do you see the future of the community to which you belong? See also Zuljan Kumar (2016).

10 Slovenian name of the Slovenes living in Slavia Veneta.

${ }^{11}$ All quotations from the interviews or literature that were originally in Slovenian, Friulian or Italian were translated into English by the authoress of the article.
} 
and Friulians experienced strong pressure to assimilate as ethnic cleansing became a part of national politics in FVG, causing almost 100,000 non-Italian speakers to leave the area (Steinicke et al., 2016, p. 53). According to the interviewee's opinion, people are "only now becoming confident in being Friulians" (A. M., 2013).

However, as indicated in the last part of the statement of the Friulian speaking female, due to recent changes in society - brought by EU policies towards decentralization and emphasis on regional and local characteristics (cuisine, architecture, language, etc.), which force the authorities in financial promotion of the activities on regional and local levels, and which, consequently, have changed the prevailing language ideology about Italian as the only correct means of communication and as the symbol of prestige - we can note changes in the attitude of the Friulians and Slovenes, living in the Province of Udine, towards both dialectal and standard Slovenian and Friulian. This has been experienced also among young Friulians and Slovenes, as stated by a teacher of Friulian, that "young people no longer have prejudices, still less a sense of inferiority" (A. M., 2013).

As already pointed out, minority, regional and local languages no longer symbolize backwardness. To the interviewer's question "what is the motive for learning Friulian", one of the interviewees answered, "to feel as part of this territory" (W. C., 2012). This feeling of loyalty to the language of the territory presents a new attitude towards a minority, regional and local language, which is in opposition with the prevailing attitude of the past, when speaking Friulian meant "you are not able to speak Italian properly, so you are not a cultivated person, worth being respected" (A. M., 2013). The same interviewee underlines the importance of the minority institutions, like Societât Filologjiche Furlane, it. Società Filologica Friulana (Friulian Philological Society) for ordinary people, because

"seeing what such institutions do [promote Friulian by producing scientific books and reviews as well as pieces of art and literature in Friulian etc.], ${ }^{12}$ they realized Friulian is a 'serious language' and not some 'worthless speech"' (A. M., 2013).

"Statistics is still low," underlines one of the interviewees, "but more and more young people understand that Europe supports multilingualism and understands it is a value" (P. S., 2013; see also Coluzzi, 2015, p. 508; Fusco 2015, pp. 212-213).

The changed attitude of governments towards minority, regional and local languages is of utmost importance, yet it is not enough. The interviewees pointed out that regional and local consciousness has to develop among people themselves. It cannot be imposed from the outside. That is precisely what has happened among the westernmost young Slovenes of the remote Ter/Torre Valleys ${ }^{13}$ in FVG, where new local consciousness has been gradually developing:

"These places are economically and socially marginal. However, the situation is no longer as critical as it used to be. There are young people who remain in valleys, because they see sense, their own role in trying to lift this community. We have never had so many young people before, conscious, creative people among us. When I started, the situation was much sadder. Now, consciousness is present, I can see it. I can also see the willingness to invest their knowledge, their will, towards changes in this area to make it flourish. There are young people in the Ter/Torre Valleys, who are aware of the wealth of these areas, who want to grow, to develop, to promote bilingualism. You cannot impose this on anyone from the outside" (J. N., 2012).

Some of the Slovenes believe that the relationship with the Slovenian language and identity has always been strong, but was, due to various pressures, concealed in the past. Today, however, because of the changed social conditions, Slovenes resonate it beyond their community:

"In my opinion, the sense of identity was very strong in the past, but was not expressed, due to pressures, oppositions. Nowadays, there are fewer problems and therefore, people

\footnotetext{
${ }^{12}$ For further information on Societât Filologjiche Furlane see: http://www.filologicafriulana.it/easyne2/societa/statutoe-regolamento.

${ }^{13}$ The Ter/Torre Valleys form the western part of Slavia Veneta. The inhabitants speak a very archaic Ter/Torre Valley dialect of Slovenian.
} 
are not afraid. Bilingual school, for example, is visited by more than a hundred pupils, who also come from mixed and Italian marriages and this school is appealing to them. It was not easy to stand out, to excel at the beginning. In my opinion, it is much more widespread now, I do not know why, there is no more pressure, we are more powerful, borders collapsed" (M. N., 2013).

The majority of interviewees notice a big difference between the past and the present in the awareness of the existence of multiculturalism in the Province of Udine. This has become something normal in both, the majority and minority language communities:

"Being a Slovene has become something normal, but it was not normal twenty years ago. We collaborate with the Municipality of Cividale, this is understood as something ordinary, because they see it as normal. Because people from all sides understand it as something normal, that this is a part of everyday life, that it is a value that has to be cherished. This is what we need, the normalization of relations" (L. T., 2012).

According to Slovenian and Friulian interviewees, an ever-increasing presence of Slovenian and Friulian in public life ${ }^{14}$ of the Province of Udine can be noticed in recent years: on billboards, in the media, ${ }^{15}$ at different institutions, at schools, although the process is still very slow and "we still have a long way to go from writing to realisation" (W. C., 2012).

The use of Friulian language is increasing in the town of Udine, where the Venetian dialect of Italian prevailed in the past:

"The Friulian language in Udine is more prominent today than a few decades ago, when it was [...] in the town, offices, army perceived as socially 'obscene, crude' language, suitable perhaps only for pubs." (M. S., 2013, p. 40).

Schools are the key for spreading the use of Slovenian and Friulian languages. In many families, Slovenian children who attend bilingual school and Friulian children attending courses of Friulian language, can communicate in these languages only with their grandparents, because their parents were not taught their mother tongue, as one of the interviewees states, "in the countryside today's parents do not speak Friulian, but grandparents do, every older man in the countryside speaks Friulian" (A. M., 2013). Yet, parents encourage their children to learn it, because, despite the fact that they themselves were raised in denial of their own identity, they feel loyalty to the Slovenian/Friulian communities. The sociolinguistic situation in the area over the last five decades has been well described by one of the Friulian interviewees:

"I was born in the 1970s, when the linguistic dynamics was quite different as it is today. Friulian language was, at least in villages, still very much alive. But perception of its value was very low. My parents were speaking Friulian to each other, with their brothers, sisters and parents. When I started attending kindergarten and school, teachers requested that parents speak Italian with their children at home in order not to hinder the progress in learning Italian. Therefore, my parents and relatives (but not grandparents) always spoke in Italian to me. This is a difficulty, which I cannot get rid of to this day. When people speak to me in Friulian, I answer in Italian. This happens with people that are not my family. Although parents spoke to me in Italian, Friulian was the language I was hearing everywhere around me. It was the language of my surroundings, my land. So I was used to it. Friulian became my first language of communication to me. Today, without a doubt, it is 'my language'. Some thoughts can fully be expressed only through the Friulian language" (C. P., 2013).

As a consequence of the circumstances in the past, an interesting gap between the use of language and the sense of belonging to a community can be noticed among the Slovenes and the Friulians. There are people, on the one hand, who master their mother tongue, but they do not feel as a part of the community, and others, on the other hand, who have a strong sense of

\footnotetext{
${ }^{14}$ Public life is here understood as formal and informal speech situations outside the speaker's family.

15 Print and other media, especially the internet and Radio Onde Furlane, which has broadcasted since 1980, partly offer a different perspective on minority languages (M. P., 2013, p. 40).
} 
belonging to the community and no knowledge of the language, as narrated by the principal of a bilingual school:

"There are people, on the one hand, who speak normal Slovenian dialect and may not speak proper Italian, and they argue that they are Italians and they do not have any connections to Slovenes. On the other hand, there are people who are not familiar with the Slovenian dialect and yet, they see themselves as Slovenes. This situation is, at least partly, a result of introducing the Slovenian language to school. The importance of our school is not so much in teaching Slovenian, but in the fact that the school itself offers an incentive to return the Slovenian language to homes, to family communication" (Ž. G., 2003).

In this sense, Slovenian and Friulian cultural organizations strive to step up in the use of their mother tongue, i.e. introduce it to the areas that are not connected to the 'fireplace' but "with those areas of life where Italian language is traditionally dominant" (W. C., 2012). Thus, recently, for example, cartoons have been dubbed to Friulian, reviews for young people have been written in Friulian, scientific vocabularies has been created in Friulian and new innovative cultural contents have raised in both communities, thereby seeking to attract young people who show affection towards their mother tongue to join the 'Friulian/Slovenian thing'.

A particular challenge of how to preserve or revive the disappearing language, culture and identity, remains precisely in how to attract young people. Innovative approaches to culture are one of the answers. There are more good practice examples of how the traditional culture of the local environment can be popularized among the Friulians and Slovenes in the Province of Udine, like SUNS Europe, the European Festival of Performing Arts in European Minority Languages in Udine, Senjam beneške pesmi/Festival della canzone delle Valli del Natisone in Liessa/Lesa, Postaja Topolove/Stazione Topolò etc. All three would deserve a more detailed presentation for the innovative approaches they are employing in the field of art. However, only the latter will be presented in the following chapter due to the limited space. I have chosen it, because while today the village of Topolove is beautifully restored - thanks to the festival which brings a combination of most advanced artwork search with the collaboration of local people and especially, local children - thirty years ago, the place was completely desolate and could not even be found on the map (Ruttar \& Miorelli, 2003; Ruttar, 2012).

\section{The importance of reinterpretation of a culture and tradition for its inhabitants and their language through art - example Postaja Topolove/Stazione Topolò}

Topolove is a village situated in the municipality of Grimacco/Grmek in the north-eastern part of FVG, $580 \mathrm{~m}$ above the sea level and close to the Slovenian-Italian state border. It lies "at the end of the path" (Ruttar \& Miorelli 2003), surrounded only by forests and with no basic services, such as a bus connection, an inn, a shop. The decay started with the period of fascism, when the inhabitants suffered from strong pressures of Italianization, and continued during the cold war between 'the East' and 'the West', which began after WW2 when the anti-communist organization Gladio, established by the Italian secret services covered the entire territory of Slavia Veneta with its secret collaborators (Ruttar \& Miorelli, 2003; Ruttar, 2012). Until the end of WW2, the village of Topolove was one of the many populous villages in Slavia Veneta with almost 400 inhabitants. In the decades following WW2, two-thirds of its inhabitants moved away, mostly to Belgian mines. Those few who remained began to experience a psychological blockade with fear and suspicion as an everyday practice. The whole territory of Slavia Veneta became a poor region with the income per inhabitant being the lowest in entire Italy. Restrictions on the part of the government and fear on the part of the inhabitants changed even the use of the local Slovenian dialect into an ideology (Ruttar \& Miorelli, 2003; Ruttar, 2012; Beltrame \& Vescovo, 2005).

In such a poverty stricken environment, an art festival started entitled, "Postaja Topolovo/Stazione Topolò" (Topolove Station). It was the year 1994 and a festival of contemporary art in such circumstances seemed "almost Don Quixote adventure" (Ruttar \& Miorelli, 2003). Aided by small 
Association of artists from Slavia Veneta and the inhabitants of the village, Moreno Miorelli and Donatella Ruttar, the founders of the festival, called on 16 artists, their old friends and invited them to make mark on the village with their work of art. The only set precondition was to be inspired by the surroundings, by the village itself:

"The chosen route seemed to be the hardest, for we were not dealing with attractive murals, but with contemporary art with a clear conceptual orientation. Only a few believed in the project. Amongst them were also the mythical hairdresser Luisa (who has been our sponsor for the entire ten year) and one bank with the contribution of 500,000 Italian Liras. [...] The word soon spread out and film directors made their way to Topolove where they held sneak previews of their films, musicians came to present their music experiments, narrators and the radio arrived, especially the radio [...] which is more prone to offer attention" (Ruttar \& Miorelli, 2003).

The festival has been held annually during the first three weeks of July and has preserved the same basic concept since the very beginning: to avoid folklorism and create the most advanced artwork search, but under one condition; artists must only work under the "impression of stimuli coming from the environment", where

"past and present life in the village with happy and tragic moments, drama of the border, emigration, and the abandonment of the village, the extraordinary intensity of the nature that surrounds it, its special architecture and tradition create not merely scenery in the background but the artists true focus of inspiration" (Ruttar, 2003, p. 583).

Artists from different artistic fields (music, visual arts, film and literature) come from Slavia Veneta and from abroad at their own expenses:

"Even travel expenses are not reimbursed, and yet the artists come from New York, New Zeeland, Brazil, United States of America and other countries - or from the neighboring village - just in order to participate in this project. They are put as guests in homes, one of the best hosts being Antonella from number 95. This is where every arrival into the village receives a plate of food, a bed and is soon surrounded by a bunch of kids" (Ruttar, 2012).

The primary purpose of the founders was to remodel meanings of terms such as 'remote', 'backward', 'hinterland' and to demonstrate that geographically peripheral does not mean culturally peripheral, but on the contrary, it may denote culturally central, because "when the project is at its peak in the month of July, it is very difficult to define what is marginal and what is central" (Ruttar \& Miorelli, 2003).

The Station started with a variety of musical events that took place in barns, hay barns, yards, which were transformed to venues of artistic events by the artists themselves. Particular attention was given to local children. These were initially only listeners, but in years to follow, they were given instruments and were integrated into in a variety of musical compositions. Today, children are active participants in various events and artistic ensembles.

Thanks to Postaja, this Slovenian village which was previously sentenced to be abandoned because of the border, the cold war and emigration, is now beautifully restored and is bringing to Slovenian, Italian and Friulian cultural spaces a fresh combination of local and global. In this sense, organizers of Postaja demonstrate how to revive the identity of inhabitants of a small and remote, but spiritually rich area, not by reproducing the old cultural practices, but by reinterpreting the territory's cultural heritage in a way that is adapted to the needs and aesthetics of contemporary society.

Globally, the station represents a small step forward. But with the idea of how the local language, its culture and identity of the people who speak that language, can be placed in a global world, it opened the way for revitalization of already disappearing languages, cultures and identities. Namely, with each local language we preserve, we retain much more than just words: we keep the uniqueness of expressions and ways of thinking that symbolizes the uniqueness of the individual and his thinking. We preserve unique knowledge of the system, which carries 
the experience of living in a particular geographical area, climate, including cultural heritage, traditional tales, beliefs and mythological traditions.

\section{Conclusions}

The study has examined the sociolinguistic situation in the Slovenian and Friulian minority groups in the Province of Udine by researching their mother language maintenance, linguistic practices and the construction of group and individual identities within the theoretical framework of language ideology. Namely, the fact that in multilingual situations minority-language speakers constantly make choices on the use of language, highlights the fact that their choice is not primarily a linguistic issue, but has to do with power, prejudice, discrimination and subordination. Language maintenance (or language loss) thus considerably depends on political and social factors. The findings illustrate that in the past, the glorification of Italian and marginalization of Slovenian and Friulian were key elements of language ideology in the broader social context. The minority status of both languages was rooted in ideological beliefs about their limited utility. However, the study into the sociolinguistic situation of the two minority groups today has shown that the implementation of EU policies of promoting linguistic diversity and multilingualism - both have become Europe's strategic objectives, demonstrated by the institution in January 2007 of a European Commissioner for Education, Culture, Multilingualism and Youth (cf. DGS, Education and Culture) - has brought positive results, i.e., the change in the language ideologies about, on the one hand, Italian as the only correct and at the same time most prestigious means of communication in the society, and, on the other hand, Slovenian and Friulian as the languages that represent backwardness and lack of education. The use of the Slovenian and Friulian languages, neither their standard nor their local varieties in the Province of Udine, no more represents lack of prestige, poverty and low education rate; on the contrary, it represents deep loyalty to the territory and its cultural heritage.

Based on the success of Postaja Topolove/Stazione Topolò, a festival that began in difficult political circumstances, we can confidently state that disappearing language and its culture can be reawakened through art and cultural activities by employing new concepts that are adapted to the needs of contemporary society.

It is also important to point out that the local population be an actor in reawakening the regional or local consciousness, because the loyalty to the territory has to rise from the group itself, it cannot be imposed from the outside. In this context, it is worth emphasizing that school has a key role in increasing the students' awareness of language ideologies. This is especially important for the Friulians who should strive for the introduction of Friulian as a language of instruction (beside Italian) into school on the primary level. Slovenes, on the other hand, will have to strive for the introduction of Slovenian into school on the secondary level. By that, teachers and students will be given agentive roles in constructing and deconstructing ideologies which represent one of the most important factors for the survival of a language or its loss.

Finally, it is also important to note, that contemporary interpretations of heritage no longer denote only "memorial monuments or folk dwellings, but also experiences, memories, skills and behavior of ordinary people" (Fakin Bajec, 2016, p. 42), so in this context, the visibility of a certain language either outside private sphere or in a linguistic landscape does not just index a reality, i.e. the use of one or more languages within a community, but contributes to the symbolic construction of a given space.

Let me conclude the paper with the words of Gianfranco D'Aronco, devoted to the Friulians:

"Language is the most precious bond that we have with our ancestors and our land. [...] Modern development is pointed towards globalization. If we do not resist now, the future us will be satisfied and happy, all eating the same frozen and warmed up meals and we all will speak only Italian. Later, the Italian will be perceived as a dialect and we will all speak English. What is the beauty in being all the same, even think the same thoughts?" (D'Aronco, Cisilino, 2012, p. 47). 
[1] Bogatec, N., et al. (2004). Slovene. The Slovene Language in Education in Italy. Ljouwert/Leeuwarden: Mercator-Education.

[2] Bourdieu, P. (2009). Language and symbolic power. Cambridge; Malden (MA): Polity Press.

[3] Burelli, A. (2011). Frakeki. Friulian language literacy in preadolescent children. Friulian Journal of Science 14, 27-43. DOI: 10.1787/9789264112995.

[4] Cisilino, W. (2014). Laws for the Protection of the Friulian Language. In Mucignat, R., ed., The Friulian Language. Identity, Migration, Culture (pp. 15-27). Newcastle upon Tyne: Cambridge Scholars Printing.

[5] Cisilino, W. (2015). Il quadro giuridico. In Heinemann, S. R. \& Melchior, L., eds., Manuale di linguistica friulana (pp. 475-491). Berlin, Boston: De Gruyter.

[6] Coluzzi, P. (2015). Il friulano: confronto con alter lingue minoritarie. In Heinemann, S. R. \& Melchior, L., eds., Manuale di linguistica friulana (pp. 492-510). Berlin, Boston: De Gruyter.

[7] Creese, A. \& Blackledge, A. (2011). Separate and Flexible Bilingualism in Complementary Schools: Multiple Language Practices in Interrelationship. Journal of Pragmatics 43, 196208. DOI: 10.1016/j.pragma.2010.10.006.

[8] D'Aronco, G. \& Cisilino, W. (2012). Sorestants e sotans. Intervista sul Friuli. Udine: La biblioteca del Messaggero Veneto.

[9] Dorian, N. C. (2010). Disciplinary and Methodological Approaches: Linguistic and Ethnographic Work. In Fishman, J. A. \& García, O., eds., Language \& Ethnic Identity. Volume I Disciplinary and Regional Perspectives (pp. 89-106). Oxford, New York: Oxford University Press.

[10] Dow, J. R. (2010). Regional Perspectives and Ethnic Identity Study of Language: Western World, In Fishman, J. A., García, O., eds., Language \& Ethnic Identity. Volume I Disciplinary and Regional Perspectives (pp. 221-236), Oxford, New York: Oxford University Press.

[11] Fakin Bajec, J. (2011). Procesi ustvarjanja kulturne dediščine. Kraševci med tradicijo in izzivi sodobne družbe. Ljubljana: Založba ZRC, ISN ZRC SAZU.

[12] Fakin Bajec, J. (2016). Cultural heritage and the Role of Voluntary Associations in the Process of Achieving Sustainable Development in Rural Communities. Studia Ethnologica Croatica 28, 21-45. DOI: 10.17234/SEC.28.2.

[13] Fishman, J. A. (2001). Can Threatened Languages Be Saved? Cleveton, UK: Multilingual Matters. DOI: 10.1017/S0047404503221059.

[14] Fishman J. A. (2010). Sociolinguistics: Language and Ethnic Identity. In Fishman J. A. \& García, O., eds., Language \& Ethnic Identity. Volume I Disciplinary and Regional Perspectives xxiii-xxxv, Oxford, New York: Oxford University Press.

[15] Frau, G. (2015). Storia linguistica esterna. In Heinemann, S. \& Melchior, L., eds., Manuale di linguistica friulana, 73-93. Berlin, Boston: De Gruyter.

[16] Fusco, F. (2015). Veneto. In Heinemann, S. \& Melchior, L., eds, Manuale di linguistica friulana (pp. 296-315). Berlin, Boston: De Gruyter.

[17] Garcia, O. (2010). Languaging and Ethnifying. In Fishman, J. A. \& García, O., eds., Language \& Ethnic Identity. Volume I Disciplinary and Regional Perspectives (pp. 519-533). Oxford, New York: Oxford University Press.

[18] Grof, C., Pilote, A. \& Vieux-Fort, C. (2016). "I am Not a Francophone": Identity Choises and Discourses of Youth Associating With a Powerful Minority. Journal of Language, Identity \& Education, 83-99. DOI: 10.1080/15348458.2015.1137476.

[19] Hall, S. (1997). Introduction. In Hall, S., Representation: Cultural representations and signifying practice (pp. 1-11). London: The Open University. 
[20] Heinemann, S. (2015). "Questione ladina". In Heinemann, S. \& Melchior, L., eds., Manuale di linguistica friulana (pp. 57-72). Berlin, Boston: De Gruyter.

[21] Huntington, P. S. (2004). Who are we? America's Great Debate. New York: Simon \& Schuster.

[22] Huss, L. \& Lindgren, A.-R. (2010). Regional Perspectives in the Study of Language and Ethnic Identity: Scandinavia. In Fishman, J. A., García, O., eds., Language \& Ethnic Identity. Volume I Disciplinary and Regional Perspectives (pp. 255-268). Oxford, New York: Oxford University Press.

[23] lannàccaro, G. \& Dell'Aquila, V. (2015). La situazione sociolinguistica. In Heinemann, S. \& Melchior, L., eds., Manuale di linguistica friulana (pp. 453-474). Berlin, Boston: De Gruyter.

[24] Joseph, E. J. (2004). Language and Identity. National, Ethnic, Religious. New York: N. Y. Palgrave MacMillian.

[25] Križman, V. (2013). Furlanska identiteta [diploma thesis]. Nova Gorica: Univerza v Novi Gorici.

[26] Kroskrity, P. V. (2010). Language Ideologies. Handbook of Pragmatics 14-24. DOI: 10.1075/hop.14.lan6.

[27] Logar, T. \& Kenda Jež, K., eds. (1996). Dialektološke in jezikovnozgodovinske razprave. Ljubljana: ZRC SAZU, Inštitut za slovenski jezik Frana Ramovša.

[28] Makuc, N. (2015). Early modern provincial identity in the border area between the Venetian Republic and the hereditary lands of the Austrian branch of the House of Habsburg. Historijski zbornik, 68(1), 1-14.

[29] Markelin, L., Husband, C. \& Moring, T. (2013). Sámi Media professionals and the Role of Language and Identity. Sociolinguistica 27, 101-115.

[30] Marriou, E. (2012). Pontian Greek Adolescents: the Negotiation of Identities in an Urban Context in Northern Greece. In Gardner, S. \& Martin-Jones, M., eds. Multilingualism, Discourse and Etnography (pp. 67-81). New York, NY: Routledge.

[31] Melchior, L. (2015). Friulano nei mass media. In Heinemann, S. R. \& Melchior, L., eds., Manuale di linguistica friulana (pp. 553-574). Berlin, Boston: De Gruyter.

[32] Mezgec, M. (2016). Linguistic landscape as a mirror: the case of the Slovene minority in Italy. Razprave in gradivo 77, 67-85.

[33] Moseley, C., ed. (2010). Atlas of the World's Languages in Danger, $3^{\text {rd }}$ ed. Paris: UNESCO Publishing.

[34] Mucignat, R. (2014). Friuli: a Small Homeland and the Age of Transnationalism. In Mucignat, R., ed., The Friulian Language. Identity, Migration, Culture (pp. ix-xxii). Newcastle upon Tyne: Cambridge Scholars Publishing.

[35] Padilla, A. M. \& Borsato, G. N. (2010). Disciplinary and Methodological Approaches: Psychology. In Fishman, J. A. \& García, O., eds., Language \& Ethnic Identity. Volume I Disciplinary and Regional Perspectives (pp. 5-16). Oxford, New York: Oxford University Press.

[36] Pavlenko, A., Blackledge, A. (2004). Negotiation of Identities in Multilingual Contexts. Cleveton, UK: Multilingual Matters.

[37] Petris, C. et al. (2014). Friulian. The Friulian Language in Education in Italy. Ljouwert/Leeuwarden: Mercator-Education.

[38] Picco, L. (2008). The "Sportis" project: promotion of the Friulian language and investigations on the mental images held by students of the Udine University. Friulian Journal of Science $10,107-121$. 
[39] Pietkäinen, S. (2012). Experiences and Expressions of Multilingualism: Visual Ethnography and Discourse Analiysis in Research with Sàmi Children. In Gardner, S. \& Martin_Jones, M., eds. Multilingualism, Discourse and Etnography (pp.163-178). New York, NY: Routledge.

[40] Preston, P. W. (1997). Political/Cultural Identity. Citizens and Nations in a Global Era, London: Thousand Oaks, New Delhi: Sage Publications.

[41] Ramovš, F. (1995). Kratka zgodovina slovenskega jezika I. Ljubljana: ZRC SAZU.

[42] Rizman, R. (2003). Globalizacija in kultura: konflikt ali sinergija? In Vidovič Muha, A., ed., Slovenski knjižni jezik - aktualna vprašanja in zgodovinske izkušnje: ob 450-letnici izida prve slovenske knjige. Obdobja 20 (pp. 27-42). Ljubljana: Center za slovenščino kot drugi/tuji jezik pri Oddelku za slovenistiko Filozofske fakultete.

[43] Ruttar, D. (2003). Topolovo, dar in ljubezen. In Constantini, E., ed., Dobrodošli v Furlaniji. Dalnji zahod, nikoli tako blizu (pp. 583-585). Udine: Societât filologjiche furlane.

[44] Salimbeni, F. (2014). History, Language and Society in Friuli (Thirty years later). In Mucignat, R., ed., The Friulian Language. Identity, Migration, Culture (pp. 2-14). Newcastle upon Tyne: Cambridge Scholars Publishing.

[45] Schmidt, U. (2008). Language Loss and the Ethnic Identity of Minorities [ECMI Issue Brief No. 18]. Flensburg: European Centre for Minority Issues.

[46] Sillani, S., Rosa, F. \& Nassivera, F. (2011). Measuring the reactivity of bilingual consumers to an alternative use of languages: a case study for the Region Friuli Venezia Giulia. Friulian Journal of Science 16, 59-75.

[47] Steinicke, E., Jelen, I., Lieb, G. K., Löffler, R. \& Čede, P. (2016). Slovenes in Italy: a fragmented Minority. European Countryside 8(1), 49-66. DOI: 10.1515/euco-2016-0004.

[48] Susič, E., Janežič, A. \& Medeot, F. (2010). Indagine sulle comunità linguistiche del Friuli Venezia Giulia: tutela e normativa: slovensko, deutsch, furlan. Udine: Regione autonoma Friuli Venezia Giulia.

[49] Štih, P. (2013). The Slavic settlement and ethnogenesis. In Luthar, O., ed, The land between: a history of Slovenia (pp. 81-92). Frankurt am Main: P. Lang.

[50] Van Dijk, T. A. (1996). Discourse Studies. A Multidisciplinary Introduction, vol. 2. London: Sage.

[51] Vassberg, L. (1993). Alsatian Acts of identity. Language Use and Language Attitudes in Alsace, Cleveland, Philadelphia, Adelaide: Multilingual Matters.

[52] Vicario, F. (2006). La lingua friulana. In Cisilino, W., ed., Friulano lingua viva. La communità linguistica friulana (pp. 75-101). Udine: Provincia di Udine.

[53] Vicario, F. (2015). Il friulano. Una lingua nel cuore dell'Europa. In Heinemann, S. \& Melchior, L., eds, Manuale di linguistica friulana (pp. 21-40). Berlin, Boston: De Gruyter.

[54] Vidau, Z. (2012). Unresolved questions concerning the public use of minority and regional languages in interactions between municipal and provincial administrations and the public in the region of Friuli-Venezia Giulia in Italy. European yearbook of minority issues 11, 143166.

[55] Vidau, Z. (2013). The Legal Protection of National and Linguistic Minorities in the Region of Friuli Venezia Giulia: A Comparison of the Three Regional Laws for the Slovene Linguistic Minority for the Friulian Language and for the German-speaking Minorities Razprave in gradivo, 70, 27-52.

[56] Vidau, Z. (2015). Intercultural relations between the Slovene national minority and the majority population in Italy after the independence of Slovenia. Research in social change 7 (3), 283-317.

[57] Weedon, C. (1997). Feminist Practise and Poststructuralist Theory. Malden, MA: Blackwell. 
[58] Williams, C. H. (2010). Regional Perspectives in the Study of Language and Ethnic Identity: the Celtic World. In Fishman, J. A. \& García, O., eds., Language\&Ethnic Identity. Volume I Disciplinary and Regional Perspectives (pp. 237-254.). Oxford, New York: Oxford University Press.

[59] Zuljan Kumar, D. (2003). Vloga narečja v družbi danes in jutri, Primorska srečanja 27 (263), 2-11.

[60] Zuljan Kumar, D. (2011). Jezik, skupnost, identiteta: odnos do prvega (maternega) jezika v času globalizacije (primer Beneških Slovencev in Furlanov). Goriški letnik 35, 229-242.

[61] Zuljan Kumar, D. (2016). Narodna identiteta pri Beneških Slovencih in Furlanih danes. Jezik in slovstvo, 61 (2), 7-18, 193.

\section{Other sources}

[62] Beltrame, T. N. \& Vescovo, L. (2005). Topolò: da paese a stazione. Il riutilizzo di un luogo. In Gri, G. P. \& Pascolini, M., eds., Scarti e abbandoni. Udine: Editrice universitaria Udinese.

[63] DGS, Education and Culture. [Online] Available from:

http://ec.europa.eu/dgs/education_culture/index_en.htm. [Accessed: March 2017].

[64] REDE, (Regionalsprache.de). [Online] Available from: https://www.regionalsprache.de/atlanten-und-karten.aspx. [Accessed: April 2017].

[65] Ruttar, D. \& Miorelli, M. (2003). Stazione di Topolo. [Online] Available from: http://www.worldofart.org/english/0203/topolove_txt.htm. [Accessed: February 2017].

[66] Ruttar, D. Postaja Topolove/Stazione di Topolò. (2012) [Online] Available from: http://www.multiversoweb.it/rivista/n-01-scarti_abbandoni/postaja-topolove-stazione-ditopolo-126. [Accessed: February 2017].

[67] Statuato della Società Filologica Friulana. Approvato dall'Assemblea Straordinaria dei Soci il 23 febbraio 2003. [Online] Available from:

http://www.filologicafriulana.it/easyne2/societa/statuto-e-regolamento. [Accessed: February 2017].

\section{Interviews}

A. M. (2013). Interview $15^{\text {th }}$ July 2013.

C. P. (2013). In Križman, V., Furlanska identiteta (pp. 63-64). Nova Gorica: Univerza v Novi Gorici.

J. N. (2012). Primorske novice, $25^{\text {th }}$ March 2011. [Online] Available from:

http://www.primorske.si/Priloge/7--Val/Del-nas-je-italijanska-pa-tudi-slovenska-kultura.aspx [Accessed: February 2013].

L. T. (2012). Interview $15^{\text {th }}$ November 2012.

M. N. (2013). Interview $20^{\text {th }}$ February 2013.

M. P. (2013). In Križman, V., Furlanska identiteta (p. 40). Nova Gorica: Univerza v Novi Gorici.

P. G. (2013). Interview $18^{\text {th }}$ August 2013.

P. S. (2013). Interview $5^{\text {th }}$ May 2013.

R. D. (2003). In Zuljan Kumar, D., Primorska srečanja 27 (263), 5.

S. B. (2012). Delo, Sobotna priloga, $28^{\text {th }}$ July, 26-27.

W. C. (2012). Interview $31^{\text {st }}$ July 2012.

Ž. G. (2003). In Zuljan Kumar, D., Primorska srečanja 27 (263), 7. 